\title{
Fibroblast Growth Factor 2 Activation of Stromal Cell Vascular Endothelial Growth Factor Expression and Angiogenesis
}

\author{
Kevin P. Claffey, Kristin Abrams, Shu-Ching Shih, Lawrence F. Brown, \\ Andrew Mullen, and Martin Keough \\ Center for Vascular Biology (KPC, MK), Department of Physiology, University of Connecticut Health Center, \\ Farmington, Connecticut; and Department of Pathology (KA, LFB, AM), Beth Israel Deaconess Medical Center and \\ Harvard Medical School, Boston, and Department of Ophthalmology (S-CS), Children's Hospital, Boston, \\ Massachusetts
}

\begin{abstract}
SUMMARY: Angiogenesis is a key component of human cancer progression and metastasis. In an effort to recapitulate early events in tumor-induced angiogenesis, we have employed a subcutaneous Matrigel implant model using immunodeficient mice as hosts. Matrigel-containing fibroblast growth factor 2 (FGF-2; $1.2 \mu \mathrm{g} / \mathrm{ml}$ ) induced stromal cell infiltration into the Matrigel/skin interface within 4 days and maximal neovascularization at 7 days. Cells staining positive for the endothelial cell marker, platelet-endothelial cell adhesion molecule 1 (PECAM-1), were present in neovessels and in isolated cells within the Matrigel matrix. Immunohistochemical analysis revealed high levels of vascular endothelial growth factor (VEGF) deposited in the stromal interface present only in the FGF-2-containing but not in control Matrigel implants. VEGF expression was confirmed with in situ hybridization. High VEGF mRNA levels were observed in the infiltrating stromal cells but not in endothelial or endothelial precursors as defined by PECAM-1 staining. In vitro analysis of FGF-2-treated embryonic fibroblasts, Balb/c 3T3 cells, showed an induction of VEGF transcription, mRNA synthesis, and protein secretion as defined by transcriptional reporter, Northern blot, and ELISA assays. The FGF-2-induced VEGF expression was not dependent on select matrix adherence or signaling components because VEGF mRNA expression induced by FGF-2 was equally activated on serum, basement membrane, and fibronectin matrix substrates. Systemic application of anti-VEGF antibodies significantly repressed FGF-2-induced angiogenesis over control antibody by $88 \%(p<0.001)$. These data support an FGF-2 angiogenic model that is dependent on endothelial cell activation, stromal cell infiltration, and VEGF expression by the infiltrating stromal cell population. (Lab Invest 2001, 81:61-75).
\end{abstract}

$T$ umor-derived angiogenic cytokines have been implicated as potent positive factors for primary tumor growth and metastasis and correlate with poor prognosis (Abdulrauf et al, 1998; Axelsson et al, 1995; Dosquet et al, 1997; Gasparini and Harris, 1995; Guidi et al, 1995; Okita et al, 1998; Volm et al, 1999; Weidner et al, 1991, 1992; Wu, 1996). Because angiogenic cytokine levels detected in the clinical setting are typically from established tumors, it has been difficult to assess the role of specific angiogenic cytokines on early tumor growth and angiogenesis. The angiogenic response has been one event that significantly contributes to the transition from moderate growth of primary transformed cells to that of an established vascularized tumor (Folkman, 1992; Folkman and Hanahan, 1991). It is reasonable to hypothesize that the interaction of tumor-derived angiogenic factors

Received August 21, 2000.

This work was supported by NIH CA-64436, University of Connecticut Health Center RISE grant (KPC).

Address reprint requests to: Kevin P. Claffey, Center for Vascular Biology, E5018, Department of Physiology - MC3505, University of Connecticut Health Center, 263 Farmington Avenue, Farmington, Connecticut 06030.E-mail: claffey@sun.uchc.edu with the surrounding tissue environment will greatly affect the early oncogenic process in a positive manner.

Multiple tumor types have been defined as expressing potent angiogenic cytokines such as basic fibroblast growth factor (FGF-2), vascular endothelial growth factor (VEGF), interleukin-8 (IL-8), and angiogenin, among others (Abdulrauf et al, 1998; Dosquet et al, 1997; Kumar et al, 1998; Mattern et al, 1997; Mise et al, 1996; Potgens et al, 1995; Schmidt et al, 1999; Volm et al, 1999). Both FGF-2 and VEGF expression has been strongly correlated with vascular density, metastatic potential, and poor survival in human colon, breast, prostate, and melanoma (Abdulrauf et al, 1998; Dosquet et al, 1997; Mattern et al, 1997; Okita et al, 1998; Schmidt et al, 1999; Ueki et al, 1995; Volm et al, 1999; Xerri et al, 1996). FGF-2, which is not secreted through vesicular pathways, can be exported from cells with unique extrusion pathways or large amounts can be released on cell death (Florkiewicz et al, 1995, 1998; Kiefer et al, 1993). FGF-2 has been selectively pinpointed as an important tumorigenic cytokine in prostate cancers in which both FGF-2 and FGF-2 receptor subtypes are coexpressed (Davol and Frackelton, 1999; Ittman and Mansukhani, 1997). 
Prostate cancer cells demonstrate a high proliferative index in vitro and in vivo, likely resulting from this FGF-2/FGF-R pathway (Ittman and Mansukhani, 1997). In addition many other tumor types express FGF-2/FGF-R at high levels (Berger et al, 1999; Sumitomo et al, 1999; Tamiya et al, 1998; Ueki et al, 1995; Xerri et al, 1996; Yoshimura et al, 1998).

VEGF is also widely distributed in many tumor types and is strongly correlated with tumorigenic progression and metastasis (Berger et al, 1995; Brown et al, 1995, 1999; Guidi et al, 1995; Jaeger et al, 1995; Weidner et al, 1991, 1992). VEGF expression is positively activated by both ras and src-mediated oncogenic transformation pathways (Charvat et al, 1999; Fleming et al, 1997; Grugel et al, 1995; Okada et al, 1998; Rak et al, 1995a, 1995b; Shi and Ferrara, 1999). In addition, VEGF expression is tightly regulated with environmental stress, in particular, hypoxia and hypoglycemia (Banai et al, 1994; Carmeliet et al, 1998; Claffey and Robinson, 1996; Damert et al, 1997; Forsythe et al, 1996; Maxwell et al, 1997; Shweiki et al, 1995; Stein et al, 1995; Stone et al, 1995). VEGF, also known as vascular permeability factor (VPF), is a potent activator of microvascular permeability and is even more potent than histamine on a per molar basis (Senger et al, 1987, 1990). The level of FGF-2 and VEGF expression in tumor cells may play a critical role in tumor expansion, invasion, and metastasis. The selective effects of FGF-2 and VEGF on endothelial cells have been described to regulate cell proliferation (Goto et al, 1993), integrin expression and function (Senger et al, 1996), metalloproteinase activators (Mandriota and Pepper, 1997; Pepper et al, 1991, 1998), matrix-dependent adhesion and migration (Senger et al, 1996), cell permeability and cell-cell junction alterations (Dellian et al, 1996; Hippenstiel et al, 1998), and morphogenic differentiation and vascular lumen formation (Pepper et al, 1992). FGF-2 is a growth factor that activates a proliferative response in many cell types in addition to endothelial cells, including stromal and tissue fibroblasts (Berger et al, 1999; Ittman and Mansukhani, 1997; Sumitomo et al, 1999; Yoshimura et al, 1998). The role of FGF-2 in promoting a stromal response in relation to tumor angiogenesis has not been addressed to date.

FGF-2 has long been known to be a potent activator of angiogenesis in several types of angiogenic models in vivo, including chick chorioallantoic membrane assay (Ribatti et al, 1997; Wilting et al, 1991), rabbit, mouse, and rat corneal pocket assay (BenEzra et al, 1993; DeLisser et al, 1997; Kenyon et al, 1996; Seghezzi et al, 1998; Ziche et al, 1997), and sponge or Matrigel subcutaneous implant models in rodents (Andrade et al, 1997; BenEzra et al, 1993; Hu and Fan, 1995a, 1995b; Passaniti et al, 1992). VEGF has also been described as an angiogenic factor in vivo (Asahara et al, 1995; Dellian et al, 1996; Wilting et al, 1993), yet its potency does not appear to equate with FGF-2 in many of the assays used. This may be due to the effect of FGF-2 on multiple cell types, whereas the limited expression of VEGF receptors on selective cells, such as endothelial cells, restricts the cellular targets for this cytokine (Mandriota and Pepper, 1997). VEGF also has a relatively short half-life and is rapidly degraded in serum; thus it is likely that a continuous supply is needed for maximal activity at the angiogenic site. Interestingly, it has been shown in several of these angiogenic models that FGF-2 and VEGF, when incorporated together, are highly synergistic in their angiogenic response (Asahara et al, 1995; Goto et al, 1993; Pepper et al, 1992, 1998).

Combined, these data indicate that the functional result of FGF-2 expression in vivo may include the activation of multiple cell types in addition to endothelial cells, which promotes the angiogenic response. A question arises with respect to FGF-2 function: Does FGF-2 release result in the induction of VEGF expression in the angiogenic loci, and if so, by what cell types? Several studies have indicated that VEGF is highly expressed in the hypoxic regions of the tumor as would be expected, but is also expressed in tissue stroma (Brown et al, 1993; Flamme et al, 1998; Fukumura et al, 1998; Huang et al, 1998; Levine et al, 1998; Senger et al, 1994). The specific mechanism controlling stromal cell VEGF expression is unclear. Here we examined the potential for FGF-2 to regulate VEGF expression in infiltrating stromal cells using a mouse Matrigel angiogenesis model. In this model of early angiogenesis, FGF-2 strongly induces the expression of VEGF in stromal cells in vivo and is supported by similar regulation of embryonic fibroblasts in vitro. These observations suggest that tumor-derived FGF-2 promotes a stromal angiogenic response that is critical for initial tumor expansion and potentially contributes to metastasis by activating VEGF expression in stromal cells.

\section{Results}

\section{FGF-2 Potently Induces Angiogenesis in the Mouse Matrigel Model in Athymic Nude Mice}

Because the growth of tumors beyond a minimal size is angiogenesis-dependent (Folkman, 1992), the initial activation of surrounding stromal tissues with tumorderived angiogenic cytokines is likely to be a critical event in tumor cell survival. Many tumor types are tightly associated with activated stroma such as breast, colon, and prostate (Brown et al, 1999; Dvorak, 1988, 1992). FGF-2 release from either initial tumor foci or large necrotic tumors may significantly affect the stromal microenvironment to promote tumor viability. To model FGF-2-driven angiogenesis, we used a modified subcutaneous Matrigel angiogenesis assay in which we have incorporated FGF-2 into the Matrigel implant. A key feature of this model is the use of immunodeficient athymic nude mice as a host for the Matrigel implants. A significant advantage of this model is the complete lack of angiogenesis with Matrigel alone because there is little inflammationdirected angiogenesis in these animals. Thus the activation and propagation of the angiogenic response is limited to the effectiveness of the angiogenic stimuli contained within the Matrigel, in this case 
FGF-2, not postinflammatory events. Because new vessels arise in the clearly defined skin/Matrigel interface, they are easily delineated using standard histological methods.

We observed a significant induction of angiogenesis in subcutaneous Matrigel implants containing FGF-2 as evident by gross appearance of the Matrigel plugs (Fig. 1A). The FGF-2-containing Matrigel implants show distinct vascular dilation around the implant, with a halo effect of new microvessel formation immediately adjacent to the implants. The control Matrigel alone showed little change in the underlying skin vasculature without the induction of microcapillaries around the Matrigel plug. It should be noted that subcutaneous macrophotographs are difficult to quantify due to the diversity of background skin vessels, interference with opaque Matrigel implants, and difficulty in normalizing illumination and contrast in various samples.

To critically evaluate the induction of new vessels, cross-sections of the Matrigel/skin interface stained with hematoxylin and eosin (H\&E) identified stromal cell infiltration and neovessels within the interface (Fig. 1A). The interface in the FGF-2-containing Matrigel implant exhibits a dense stromal staining that contains lumenal vessels filled with fixed blood cells. Quantification of blood vessels within this new stromal interface structure was performed by counting the lumenal structures that had entrapped blood cells across the whole length of the skin/Matrigel interface. Although this method underrepresents small capillary vessels, the angiogenic response to FGF-2 produces welldefined vascular structures within the interface. Five individual Matrigel implants from control or FGF-2 implants at 4 and 7 days postimplantation were analyzed in this fashion, and the results indicate a significant angiogenic response to FGF-2 with a 7-fold increase over control implants at the 7-day time point (Fig. 1B).

To more precisely measure the angiogenic response, new vessels were quantified within the skin/ Matrigel interface by positive immunostaining for the basement membrane component, mouse type IV collagen. Maximal induction of angiogenesis with FGF-2/ Matrigel was found at 7 days postimplantation when compared with control Matrigel alone (Fig. 2). Interestingly, the angiogenic response was completely resolved by 14 days postimplantation. This vascular regression was likely due to the limited amount of FGF-2 employed and an increase in stromal cellinduced degradation of the Matrigel plug.

\section{FGF-2-Induced Angiogenesis Is Complemented with Stromal VEGF Expression}

In an effort to determine whether the cells infiltrating the skin/Matrigel interface are participating in promoting the angiogenic response by expressing VEGF, both immunohistochemistry and in situ hybridization analyses were employed. Anti-VEGF antibody that recognizes dimeric VEGF was evaluated in three separate conditions: Matrigel alone, Matrigel+heparin, and Matrigel+heparin+FGF-2. The resulting angiogenic implants were used to quantify VEGF expression levels by counting positive cells within the host/Matrigel interface at 7 days postimplantation. VEGF protein was not detected in control- or heparin-containing Matrigel implants; however, the FGF-2-containing implants demonstrated a significant increase in immunodetectable VEGF primarily localized to cells within the neovascular stromal interface (Fig. 3A).

To compare this VEGF expression with endothelial cell activation associated with the angiogenic response, PECAM-1 immunostaining was also performed. Significant PECAM-1 staining in both established lumenal capillary structures and individual cells migrating within the stroma and the Matrigel matrix was observed primarily in the FGF-2-containing implants (Fig. 3A). Higher magnification shows PECAM-1 staining on the surface of newly formed vessels in the interface region of FGF-2 implants, some of which have embedded red blood cells within their lumens (arrows, Fig. 3B). Both control and FGF-2 implants show PECAM-1 staining in capillary dermal vessels. Quantification of both VEGF and PECAM-1 positive cells within the Matrigel/skin interface stromal tissue indicated coexpression of both in FGF-2 implants compared with the control Matrigel alone (Fig. 3C). These data are consistent with FGF-2, providing a distinct activation of VEGF deposition within the angiogenic stroma and promoting endothelial cell migration and vessel morphogenesis. These data do not, however, define whether the VEGF protein detected by immunohistochemistry is actually being expressed by the stromal cells themselves or is derived from some other source such as adjacent host cells in the skin.

To address this latter question, in situ hybridization was performed with antisense and control sense VEGF RNA probes to define the cells expressing VEGF. Figure 4 shows detectable VEGF mRNA only in cells infiltrating into the FGF-2-containing Matrigel implants. Interestingly, there appears to be strong up-regulation of VEGF mRNA expression within cells that had migrated into the Matrigel matrix as well as those in the interface. The quantification of silver grains in the dermis, interface, and Matrigel regions showed that VEGF antisense probe had statistically significant signal in both the interface and Matrigel regions compared with control sense probe $(p<0.01)$, thus defining specific expression over background.

To compare and contrast the expression of VEGF with that of its receptor, VEGFR-2 (flk-1/KDR), the same samples were analyzed with antisense probes to the VEGFR-2/flk-1. Clearly, the expression of VEGFR-2 was found to be restricted to newly formed vessels in the skin/Matrigel interface in a pattern similar to that observed for PECAM-1 immunostaining as would be expected for an endothelial cell receptor (Fig. 4). In addition there was little expression of the VEGF receptor in control Matrigel implants containing heparin alone, thus confirming that the neovascular response was FGF-2-dependent (data not shown). VEGFR-2/flk-1 antisense probe was also quantita- 


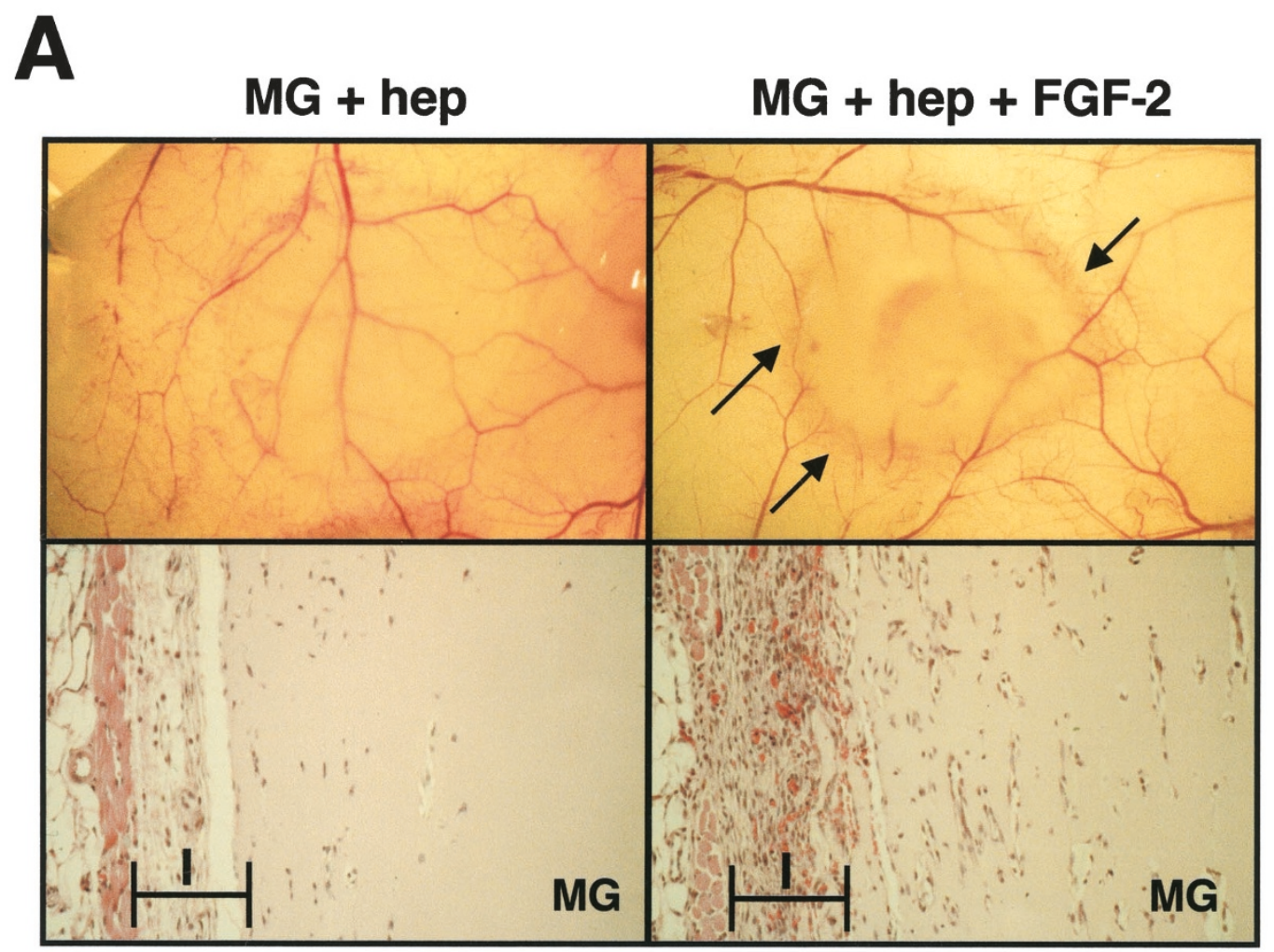

B

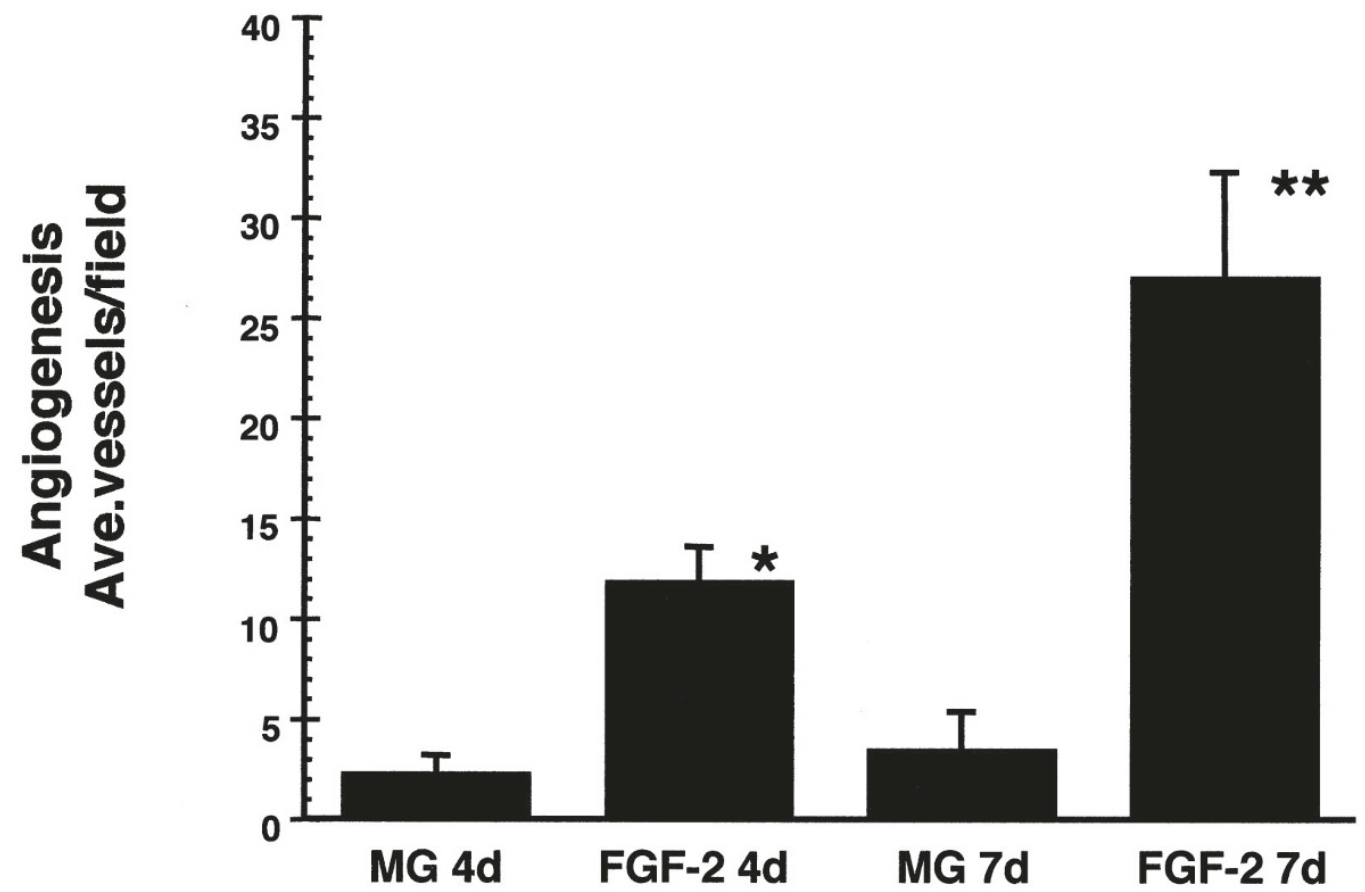

Figure 1.

Angiogenic response to fibroblast growth factor 2 (FGF-2)-Matrigel subcutaneous implants in nude mice. A, top panel, Gross photographs of Day 7 Matrigel implants with skin vessel background (original magnification, $\times 6$ ). Representative Matrigel implants with heparin alone (MG+hep) or FGF-2 (MG+hep+FGF-2) are shown. Arrows indicate the peripheral microvessel halo effect surrounding the FGF-2-containing implant. Note the control implant is translucent showing underlying skin vessels. A, bottom panel, Histologic sections and hematoxylin and eosin stained cross-sections showing the Matrigel/skin interface (I), original magnification, $\times 200$. Note the induced stromal development, cell infiltration, and capillary lumenal blood vessels in the FGF-2 but not in the control implant. B, Quantification of induced angiogenesis in the Matrigel/skin interface at two time points. The angiogenesis defined by lumenal vessels per microscopic field (original magnification, $\times 200)$ was evaluated as described in "Materials and Methods" for $n=6$. Averages of FGF-2-containing implants (FGF-2) were compared with the control at the same time (MG) and analyzed for statistical significance by Student's $t$ test; * $p<0.05 ;{ }^{* *} p<0.001$. 


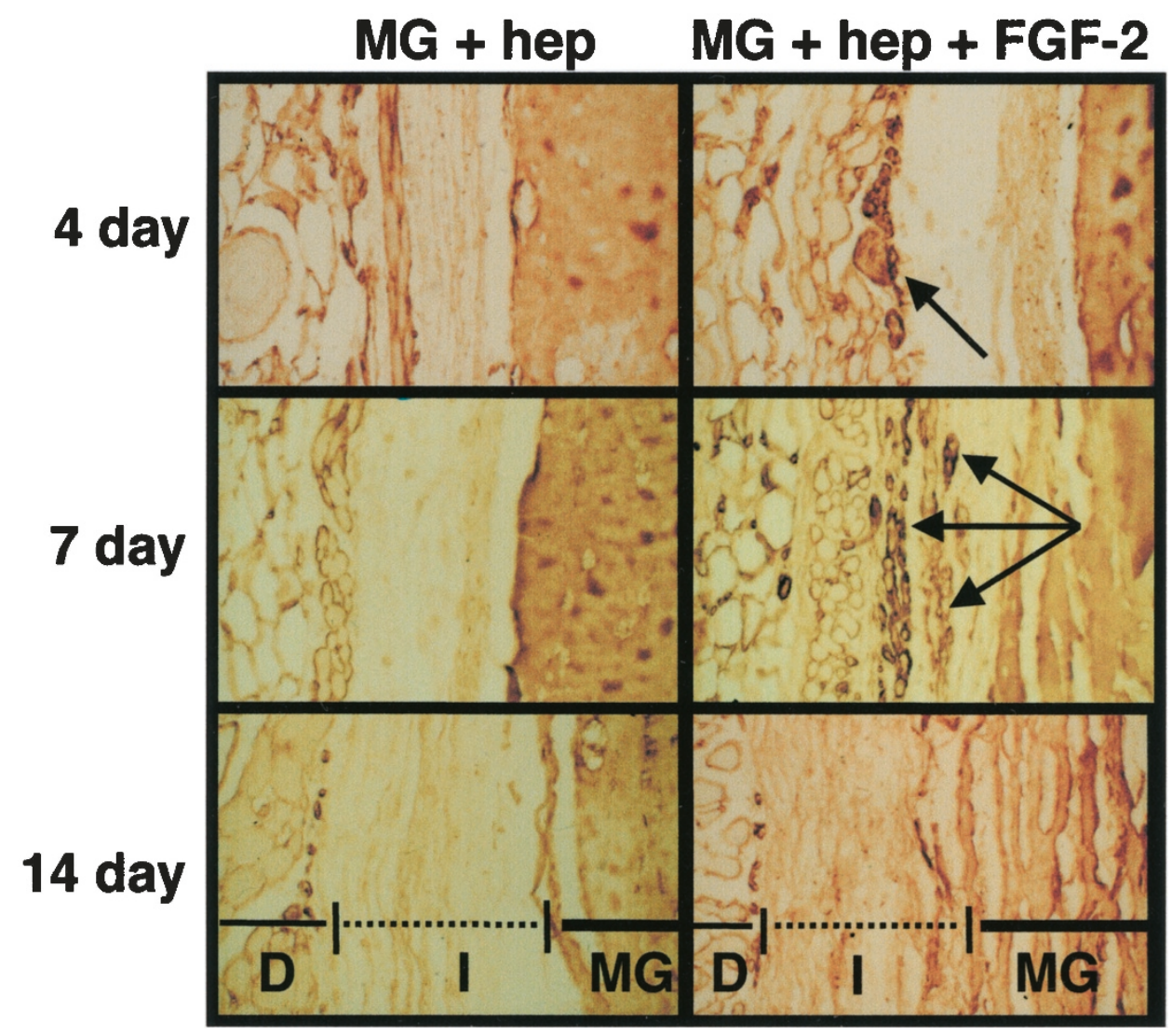

Figure 2.

Temporal induction and regression of the angiogenic response to FGF-2-Matrigel implants. Neovascular basement membrane structures were evaluated in the Matrigel/skin stromal interface using antimouse type IV collagen immunostaining. Matrigel/skin cross-sections were immunostained with anti-type IV collagen to identify stromal neovasculature derived from control implants (MG+ hep) or FGF-2 implants (MG+hep+FGF-2) isolated at 4, 7, and 14 days postimplantation. Dermis $(D)$, stromal interface $(\Lambda$, and Matrigel $(M G)$ structures are identified. Arrows depict new vessels in the stromal interface in the FGF-2-containing implant at 4 and 7 days. Note the prominent regression and Matrigel degradation at 14 days postimplantation in the FGF-2-containing implant.

tively different from control sense probe in both the interface and Matrigel regions $(p<0.005)$. Interestingly, when the VEGF receptor VEGFR-1 (flt-1) was analyzed there was no detectable expression above background by using in situ hybridization techniques (not shown). This observation is interesting, because most late-stage tumor angiogenic responses demonstrate vascular endothelial cell expression of both VEGFR-2 (KDR/flk-1) and VEGFR-1 (flt-1) receptors (Brown et al, 1999; Plate et al, 1993, 1994). However, because this is a model of relatively early angiogenic responses, the regulation of flt-1 in early versus later stage neovessels has not been defined.

\section{FGF-2 Potently Induces the Expression of VEGF in Embryonic Fibroblasts}

To examine the mechanism of FGF-2-induced expression of VEGF in stromal cells, we evaluated the effect of FGF-2 on mouse embryonic fibroblasts, Balb/c 3T3 cells. Confluent monolayers of Balb/c 3T3 fibroblasts were placed in serum-free media overnight to minimize the effects of serum growth factors and were then stimulated with FGF-2 at a concentration of $10 \mathrm{ng} / \mathrm{ml}$ for 8 hours, the maximal time of FGF-2 activation as defined in time course assays (not shown). Total RNA was isolated and Northern blot analysis performed to evaluate VEGF mRNA levels. Figure $5 A$ is a representative result showing prominent induction of VEGF mRNA in cells treated with FGF-2. As a control, the ribosome-associated protein, 36B4, was used and showed no regulation. When VEGF mRNA was quantified by phosphorimage analysis and normalized to the 36B4 control, a maximal 8-fold activation over control was observed. To compare the activation induced by FGF-2 with a known modulator of VEGF expression, cells were exposed to hypoxia $\left(1 \% \mathrm{O}_{2}\right)$ and analyzed by Northern blot. The results revealed a 10-fold activation of VEGF mRNA expression, similar to hypoxic responses observed in many other cell types (Claffey and Robinson, 1996).

Although FGF-2 appeared to rapidly induce VEGF mRNA by Northern blot, this experiment does not test whether the mRNA is translated into protein or whether secretion pathways are functional. Thus we examined the level of VEGF protein secreted by these cells by using an ELISA assay of conditioned media from control and FGF-2 treated cells over a 24-hour time course. As shown in Figure 5B, the level of VEGF detected in conditioned media in FGF-2-treated cells was significantly higher than the level in control cells 


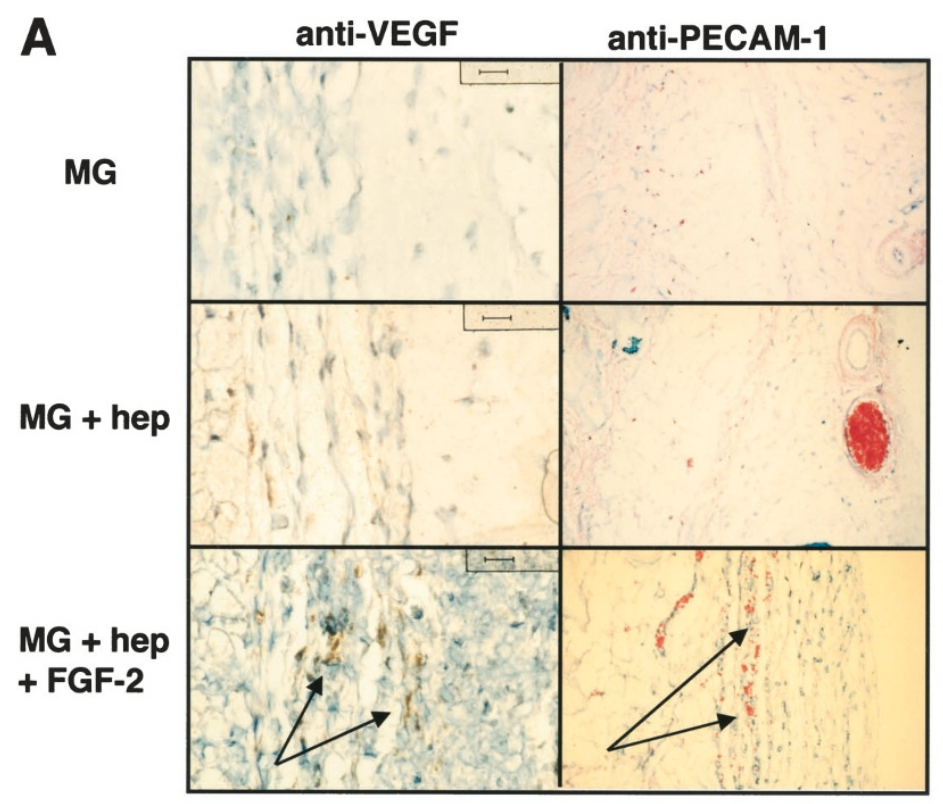

B

anti-PECAM-1
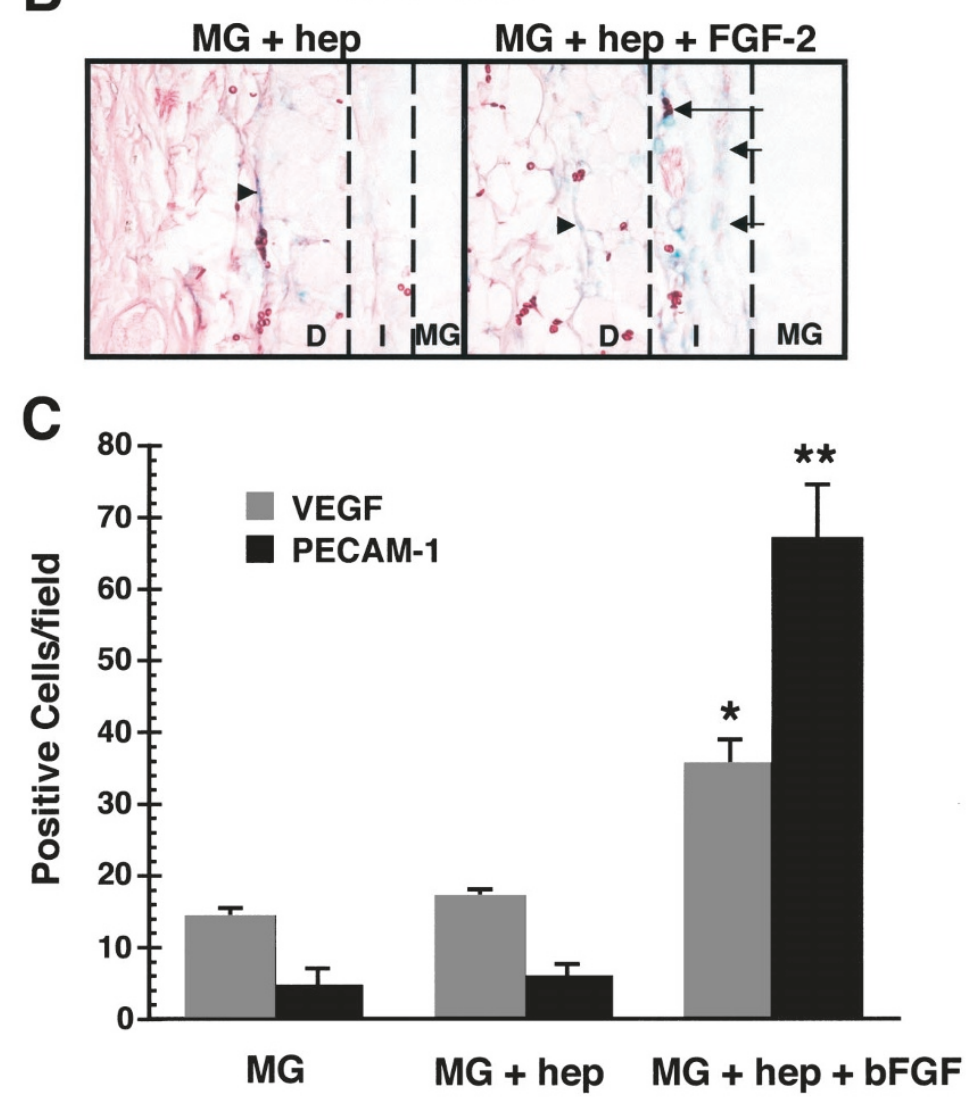

Figure 3.

Correlation of VEGF and PECAM-1 immunostaining with FGF-2-containing Matrigel implants. A, Matrigel implants containing Matrigel alone (MG), Matrigel with heparin (MG+hep), and MG with heparin and FGF-2 (MG+hep+FGF-2) were evaluated for the expression of vascular endothelial growth factor (VEGF) and platelet-endothelial cell adhesion molecule 1 (PECAM-1) at 7 days postimplantation. Note the prominent detection of VEGF (anti-VEGF) in the FGF-2-containing implant stromal interface (arrows). Very little VEGF was detected in the heparin control and none in the Matrigel control. The detection of PECAM-1 (anti-PECAM-1) was also selectively restricted to the highly angiogenic FGF-2-induced stromal interface with both lumenal vascular capillary structures and individual cells invading into the Matrigel matrix (arrows). B, Higher power view of anti-PECAM-1 staining (blue signal) in Matrigel with heparin (MG + hep) and Matrigel with heparin and FGF-2 (MG+ hep+FGF-2) (original magnification, $\times 900)$. Dermal, interface, and Matrigel regions indicated as $D$, I, and MG, respectively. Arrowheads show PECAM-1 positive capillaries in dermal regions and arrows show PECAM-1 positive vessels in the interface regions. C, Quantification of VEGF and PECAM-1 immunostaining in the FGF-2 and control Matrigel implants at Day 7 postimplantation. The number of positive cells per high-power field were averaged as described in "Materials and Methods." Statistical significance of the FGF-2 implants compared with the Matrigel + heparin control was performed by Student's $t$ test for $n=4$. * $p<0.05$ ** $p<0.001$. 

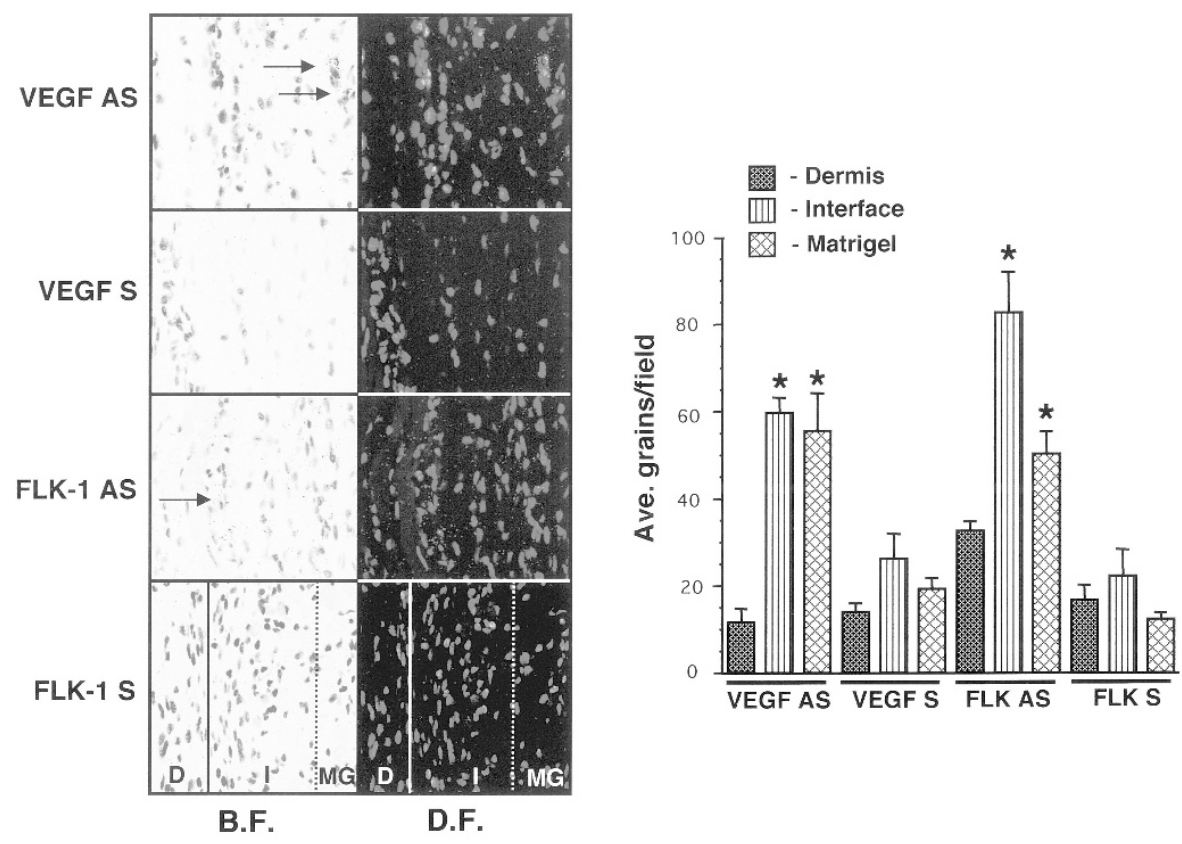

Figure 4.

Left panel, VEGF and VEGF receptor-2/flk-1 expression in FGF-2-induced angiogenesis detected by in situ hybridization analysis. VEGF was detected with antisense probe (VEGFAS) and sense control (VEGF S) in FGF-2-containing Matrigel implants (7 days). Bright (B.F.) and dark inverted (D.F.) field photographs are presented Arrows indicate strong focal cell staining. VEGF receptor-2/flk-1 was detected with antisense probe (FLK-1 AS) and sense control (FLK-1 S). Arrows indicate regions of positive staining. Dermis $(D)$, stromal interface $(\Lambda$, and Matrigel $(M G)$ are indicated. Right panel, Quantification of silver grains in the individual regions for VEGF antisense and sense and FLK-1 antisense and sense probes. The average of three fields in each region was measured and antisense compared with sense control for each region by Student's $t$ test. * $p<0.005$.

beginning at 4 hours and extending to the 8-hour time point. Because this assay is restricted to soluble secreted VEGF (ie, VEGF in the media), the total amount that might remain cell-associated would not be detected in this assay. Thus these data likely underrepresent the absolute level of VEGF being produced by the fibroblasts with FGF-2 activation. In addition, this experiment demonstrates that embryonic fibroblasts, an appropriate model cell for stromal fibroblasts, are functionally responsive to FGF-2 activation and are capable of maintaining VEGF translation and secretion pathways.

To determine whether activation of VEGF transcription is the mechanism by which FGF-2 induces VEGF in Balb/c 3T3 cells, we employed a VEGF transcriptional reporter construct in a transient transfection assay. Balb/c 3T3 cells were transfected using Lipofectamine reagent with the VEGF promoter-luciferase reporter vector in triplicate for each condition. After a 20-hour recovery period, cells were stimulated with either FGF-2 $(10 \mathrm{ng} / \mathrm{ml})$ or hypoxia $\left(1 \% \mathrm{O}_{2}\right)$ for 8 hours. Cell lysates were obtained and luciferase activity determined. Figure 5C shows the activation of VEGF transcription driven by the reporter construct with FGF-2 stimulation for 8 hours compared with the activation observed with hypoxia. In this experiment the induction observed for FGF-2 was 2-fold compared with a 2.5-fold activation with hypoxia. FGF-2 and hypoxia were both statistically significant over control $(p<0.05)$ in a Student $t$ test comparison. Thus hypoxia and FGF-2 regulate VEGF transcription in embryonic fibroblast cells in vitro.

\section{FGF-2 Activation of VEGF Expression Is Not Cell-Matrix Specific}

The observation of FGF-2-induced VEGF expression in cells localized within the Matrigel implant suggests that there might be a requirement for cell-matrix interactions in vivo. To test this hypothesis, we plated Balb/c 3T3 cells on different matrix components and evaluated adhesion and FGF-2-inducible VEGF expression. Initial experiments were performed to determine selectivity, if any, of Balb/c 3T3 cells for adherence to specific matrix components. Balb/c 3T3 cells were plated in serum-free conditions onto plastic tissue culture plates pretreated with serum, Matrigel matrix, fibronectin, laminin, and type IV collagen. Balb/c 3T3 fibroblasts adhered to the control plastic with serum, and the Matrigel and fibronectin components without serum (Fig. 6A). The cells did not adhere to vitronectin, laminin, or type IV collagen under these conditions (not shown). To determine the effect of FGF-2 on VEGF expression in Balb/c 3T3 cells attached to these specific matrices, the cells were treated with FGF-2 at $10 \mathrm{ng} / \mathrm{ml}$ for 4 hours, and total RNA was isolated and analyzed by Northern blot for VEGF mRNA. Interestingly, although the total RNA isolated from each group varied depending on cell number and adherence efficiency, the quantification of VEGF induction with FGF-2 was nearly identical for all the cells that were attached to their respective matrices (Fig. 6B). Thus given that these cells might represent a common stromal cell type, it is likely that the amount of FGF-2 contained within the Matrigel im- 


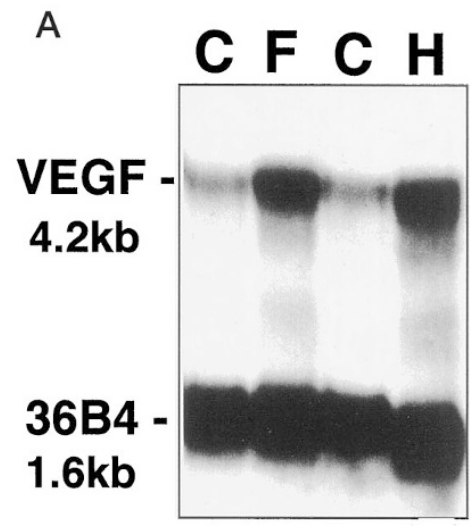

B

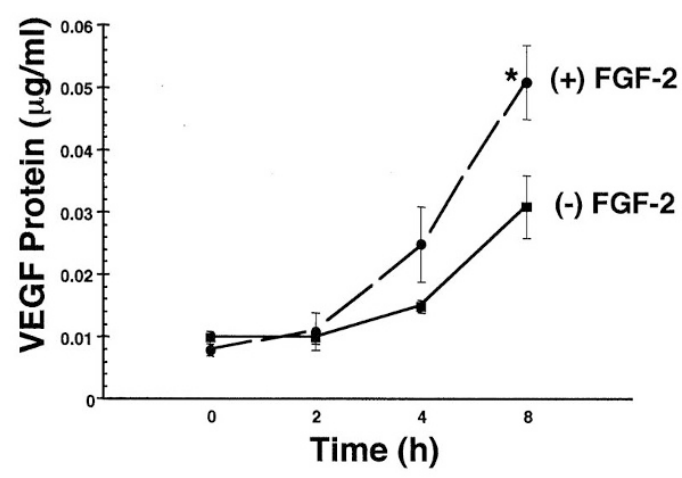

C

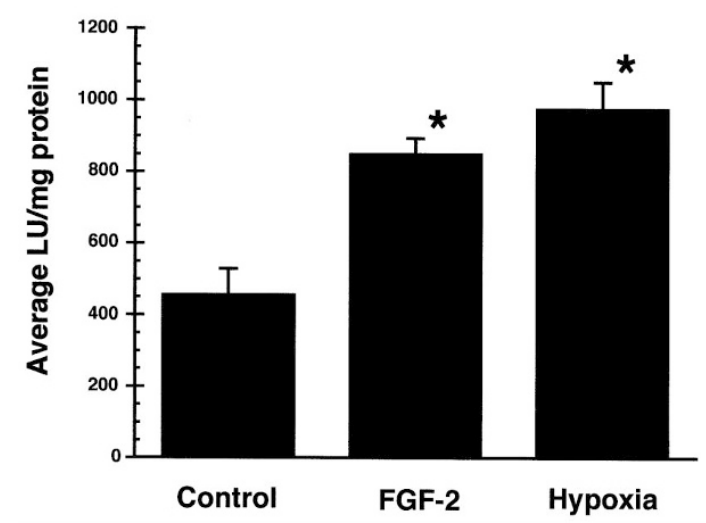

Figure 5.

FGF-2 induces VEGF mRNA and protein in Balb/c 3T3 embryonic fibroblasts. A, Serum-restricted fibroblasts were treated with FGF-2 $(10 \mathrm{ng} / \mathrm{ml})(F)$, hypoxia $\left(2 \% \mathrm{O}_{2}\right)(\mathrm{H})$, or untreated control $(\mathrm{C})$. Northern blot analysis for VEGF (VEGF) and ribosome-associated protein (36B4) was performed (exposure time: 24 hours). B, VEGF protein secretion from control (-FGF-2) or FGF-2-treated (+FGF-2) Balb/c 3T3 fibroblasts over an 8-hour time period. Triplicate plate conditioned media samples were analyzed by ELISA and represented as average VEGF $(\mathrm{ng} / \mathrm{ml}) \pm$ SEM. Statistically significant difference from untreated samples $\left({ }^{*} p<0.05\right)$. C, Transient transfection and transcriptional activation of VEGF-promoter-luciferase reporter construct. Balb/c $3 T 3$ cells were transfected in triplicate with either the VEGF promoter-luciferase construct or the pGL3 control vector. Postrecovery (18 hours), cells were treated with FGF-2 (FGF-2), hypoxia, or nothing (Contro) for 8 hours. Cell lysates were analyzed for luciferase activity and subtracted from the pGL3 control levels. Data is presented as average light units per $\mathrm{mg}$ protein \pm SEM. plant was a key determinant of FGF-2-induced VEGF expression, as opposed to a selective requirement for specific cell-matrix interactions.

\section{VEGF Expression and Function Significantly Contributes to FGF-2-Induced Angiogenesis In Vivo}

Although the FGF-2-induced angiogenic response clearly incorporates a significant activation of VEGF expression in stromal cells, the relative contribution of the VEGF cytokine to the overall angiogenic response remains unclear. To determine the role and importance of VEGF in this stromal angiogenic response, we performed an experiment designed to specifically inhibit the VEGF activity by incorporating the systemic application of a functional blocking antibody to VEGF (Asano et al, 1995; Couffinhal et al, 1998; Kondo et al, 1993). The FGF-2-induced Matrigel angiogenic assay was performed with ip injections of either control endotoxin-free nonimmune chicken antibody or the functional blocking anti-VEGF chicken antibody, as described in "Materials and Methods."

The result was surprisingly dramatic. The VEGF blocking antibody treatment significantly reduced the angiogenic response as evidenced in the gross appearance of the FGF-2-Matrigel implants compared with the control antibody (Fig. 7A). Histochemical analysis of the Matrigel implants indicated that the VEGF blocking antibody had a distinct repression effect on the total stromal cell accumulation in the skin/Matrigel interface and significantly reduced the number of cells invading into the Matrigel matrix. Concomitant reduction in neovessel formation as determined by basement membrane immunostaining with collagen type IV antibody was also observed (Fig. 7B). Quantification of the angiogenic response confirmed the gross observations: the anti-VEGF treatment showed an $80 \%$ inhibition of angiogenesis compared with control antibody. Given the observation that FGF-2 potently induces VEGF expression in stromal cells, the coordinate presence of both of these cytokines appears to be critical to promoting cell infiltration, migration, and survival, resulting in a maximal angiogenic response that can largely be eliminated with anti-VEGF therapy.

\section{Discussion}

Human tumors closely associated with adjacent stromal tissue and vasculature are likely to require complex steps to support tumor progression and development. The data linking the expression of angiogenic factors with the growth and metastasis of human tumors is highly compelling. Human breast carcinomas, for example, have a clear link between the expression of VEGF and higher metastatic rates and poor prognosis (Toi et al, 1995). However, because many of the clinical specimens being analyzed have been derived from well-developed primary or metastatic tumors, there is little mechanistic data relating to events that are driven by angiogenic cytokines in the early stages of tumor growth. Also the role for infiltrat- 
A control FGF-2
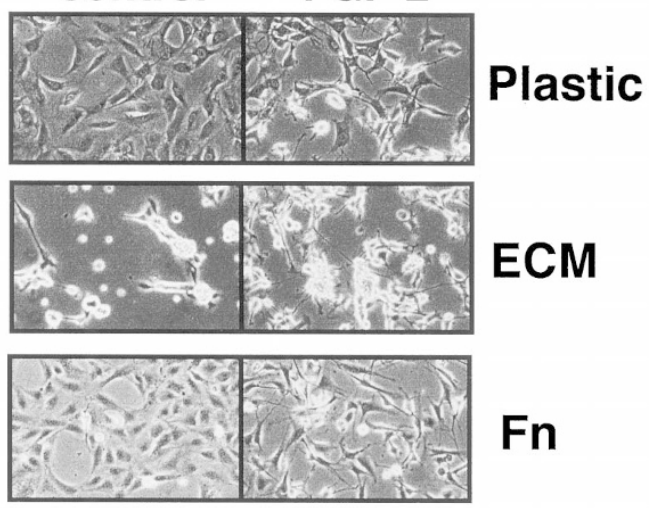

Fn

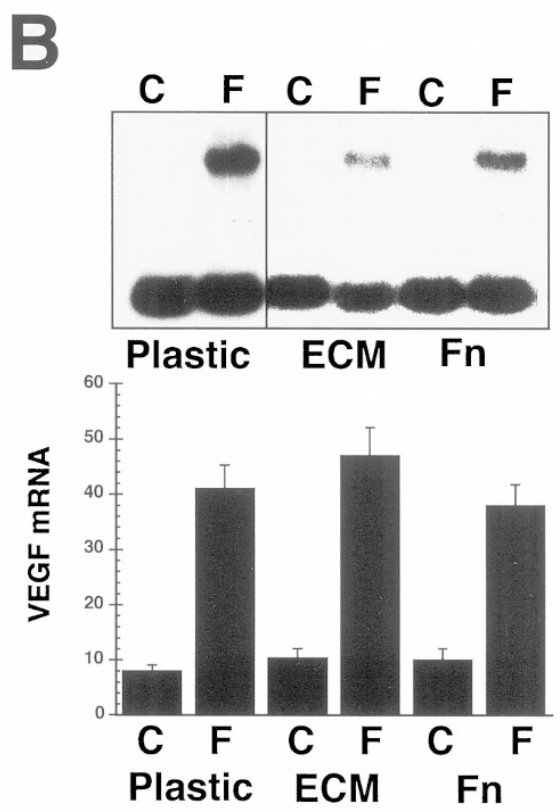

Figure 6.

FGF-2-induced VEGF expression is independent of cell adherence to attachment matrices. A, Serum-free Balb/c 3T3 cells were plated onto serum(Plastic), Matrigel- (ECM), and fibronectin (Fn)-coated plates in the presence (FGF-2) or absence (control) of FGF-2 (10 ng/ml) for 8 hours. Phase photographs denote attachment to all three matrices and activation by FGF-2 (increase in rounded cell morphology). B, Top panel, Northern blot analysis for VEGF and 36B4 control from cells on the indicated matrices in the presence $(F)$ or absence $(C)$ of FGF-2 $(10 \mathrm{ng} / \mathrm{ml})$ for 8 hours. Bottom panel, Phosphorimage quantification of the VEGF mRNA signal normalized to the 36B4 control for Balb/c 3T3 cells plated and treated on each indicated matrix. Note the nearly identical FGF-2-induced VEGF mRNA levels for each matrix.

ing host cells in promoting the angiogenic signal has not been investigated. In particular when tumor cell transformation and initial growth occurs, the release of angiogenic factors such as FGF-2 and VEGF may be critical to tumor progression and survival. Thus the effect of FGF-2 and VEGF on the infiltrating host cells may play a critical role in propagating and maintaining the earliest angiogenic signals.

The angiogenic model employed here, which largely excludes inflammation-dependent events, models the environment likely to be present in early tumorigene- sis. The induction of stromal cell expression of VEGF was found to be critical to angiogenesis activated by FGF-2 alone.

FGF-2 released from cells in developing and/or large necrotic tumors activates a critical step in the angiogenic process, that is a rapid induction of cell infiltration into the site of tumor implantation or formation. These infiltrating cells include fibroblasts, monocytes, and macrophage and endothelial cell precursors, and form a new tumor-associated stromal compartment. However FGF-2 exerts two prominent effects on these target cells. One effect is a proliferative response that expands the stromal population and promotes the deposition of extracellular matrix, thus establishing permanence in this stromal tissue. Second, FGF-2 potently activates VEGF expression in many of these stromal cells as evidenced here and in clinical samples (Abdulrauf et al, 1998; Mise et al, 1996). It was apparent that the stromal VEGF expression pattern in the stromal compartment did not match that observed for PECAM-1, suggesting that FGF-2-induced VEGF expression was distinct from endothelial cells in vivo. Thus despite observations that predict an endothelial-dependent autocrine activation through the VEGFNEGFR2 axis in FGF-2 angiogenesis (Seghezzi et al, 1998), we have not observed this to be the case in vivo. Thus in the microenvironment surrounding early tumor foci, where the release of FGF-2 is likely, the formation of new vasculature will be promoted by the combination of both FGF-2 and VEGF functions.

The selective mechanism for FGF-2-induced VEGF expression in stromal cells was modeled in vitro using embryonic fibroblasts. These tissue fibroblasts could be potently activated to express VEGF mRNA and protein to nearly the same efficiency and amplitude as hypoxia. In addition, the FGF-2-activated VEGF expression was mediated by transcriptional activation as defined with a VEGF promoter-luciferase reporter construct. Interestingly, the activation of fibroblasts by FGF-2 to express VEGF was found to be independent of cell-matrix interactions that further support a model of stromal cell dependence on FGF-2 as opposed to possible matrix-dependent VEGF expression. In this model, Matrigel alone also did not show any VEGF expression, despite having significant stromal cell infiltration.

As evidenced by our anti-VEGF antibody blocking experiments, interruption of the FGF-2/VEGF cascade quite effectively eliminated the FGF-2-induced angiogenic response. This is an exceptional inhibition, especially because the primary angiogenic cytokine present is FGF-2. Thus it could be implied that FGF-2 operates selectively through VEGF expression; however, it is more likely that the antibody treatments are highly effective at blocking VEGF functions at several levels. VEGF effects on local vascular permeability, endothelial cell differentiation, and vascular lumen formation are all VEGF-selective functions required for the angiogenic response. Inhibition of one or more of these events could promote endothelial cell apoptosis, thus deriving an amplified effect of the antibody treatment. Thus the functional role of FGF-2 to stim- 


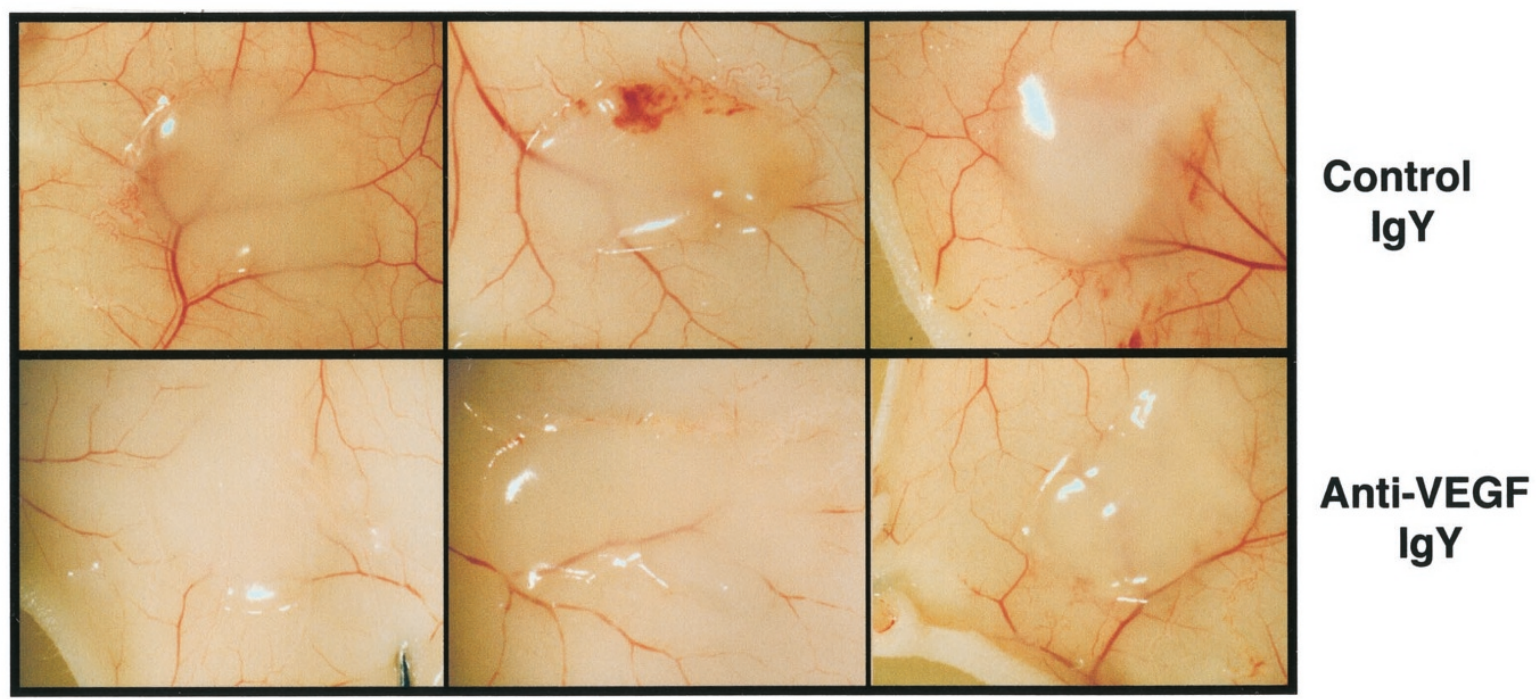

B
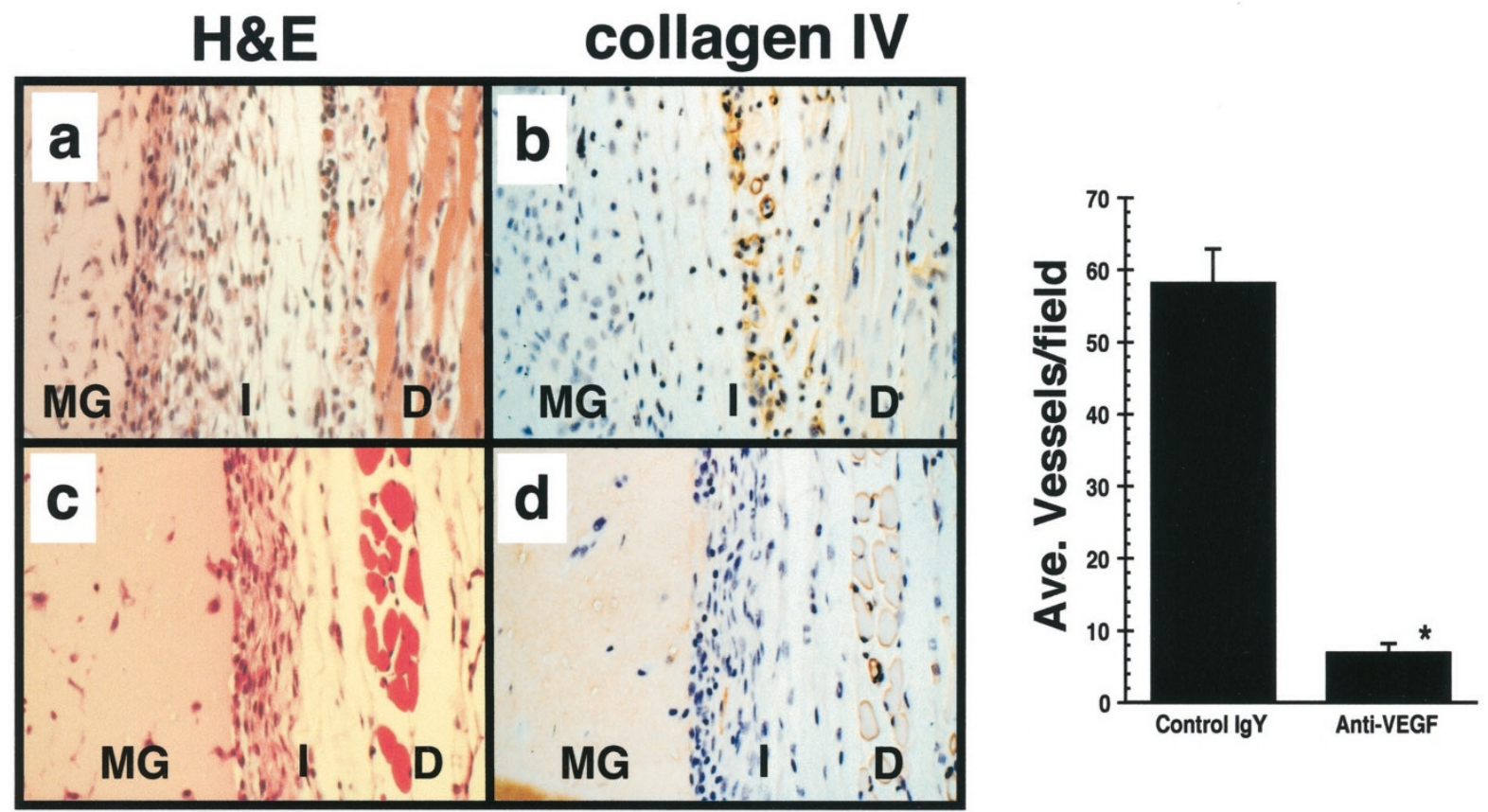

Figure 7.

Effect of systemic anti-VEGF antibodies on FGF-2-induced angiogenesis in vivo. A, Gross photographs of three representative Matrigel implants containing FGF-2 combined with systemic treatment with nonimmune chicken IgY (Control IgY) and anti-VEGF (Anti-VEGF IgY). Note the lack of associated skin vessel dilation and Matrigel coloration in the anti-VEGF group. B, Histologic evaluation of the stromal and angiogenic response induced by FGF-2 with control and anti-VEGF systemic treatments. Hematoxylin and eosin (H\&E) and antimouse type IV collagen (collagen IV) are presented for control IgY (a and b) and anti-VEGF IgY (c and d). Matrigel $(M G)$, stromal interface $(I)$, and dermis $(D)$ are indicated. Inset, Quantification of the angiogenic response in the control and anti-VEGF groups $(n=10)$ is expressed as average vessels per field \pm SEM. Statistical difference from control IgG: * $p<0.001$.

ulate stromal cell infiltration and proliferation appears to be a key element in the angiogenic process.

The expression and/or release of FGF-2 from tumors is relevant because the selection and propagation of tumor cells likely involves a balance between tumor cell growth and apoptosis. In large necrotic tumors, it is likely that FGF-2 would be released and VEGF would be produced from hypoxic cells, thus potentiating a stromal angiogenic response. FGF-2 has also been demonstrated to potentiate the re- 
sponse of endothelial cells to VEGF by upregulating the VEGFR-2 (flk-1/KDR) (Hata et al, 1999). Thus FGF-2-induced endothelial sensitivity to VEGF that is expressed within the developing stroma or secreted by tumor cells that are transformed could potentiate early tumor-associated stromal angiogenesis. The role of VEGF as a differentiation and morphogenic factor for endothelial cells is one prospective role that is required over and above those observed for FGF-2, and may be necessary to achieve a maximal angiogenic signal.

In summary, early tumorigenic events that occur during primary tumor growth and small metastatic foci inoculation could be dependent on FGF-2 and VEGF expression. Effective antimetastatic tumor therapies should therefore be directed toward multiple angiogenic cytokine targets and/or stromal tissue responses to angiogenic stimuli.

\section{Materials and Methods}

\section{Matrigel Angiogenesis in Athymic Nude Mice}

Four- to six-week-old female immunodeficient nude mice (athymic NCr-nu/nu) were obtained (Taconic Laboratories, Germantown, New York) and housed in positive pressure air filtered rooms with microisolator cages containing autoclaved bedding, food, and water. Matrigel was obtained with protein concentrations of $>15 \mathrm{mg} / \mathrm{ml}$ and endotoxin less than $1 \mathrm{EU} / \mathrm{ml}$ (Collaborative Biomedical, Bedford, Massachusetts). Endotoxin-free recombinant human FGF-2 was a gift from Praecis Pharmaceuticals (Cambridge, Massachusetts). FGF-2 was combined with heparin at a 1:5 molar ratio (heparin:FGF-2) in serum-free DMEM to obtain a $5 \mu \mathrm{g} / \mathrm{ml}$ FGF-2 concentration, and the mixture placed on ice. Three volumes of Matrigel were added, for a final FGF-2 concentration of $1.6 \mu \mathrm{g} / \mathrm{ml}$, and carefully mixed with prechilled pipet tips to prevent aeration and gelatinization. Animals were anesthetized with Avertin $(0.01 \mathrm{cc} / \mathrm{g}$ body weight, ip) and Matrigel mixtures $(0.25 \mathrm{ml})$ injected in the subcutaneous space with a prechilled tuberculin syringe (27G needle) at the dorsal midline of the back. Four to fourteen days later, animals were euthanized with $\mathrm{CO}_{2}$ and the dorsal skin dissected, retaining the Matrigel implant. Gross photographs were obtained of the Matrigel implant with a dissecting photomicroscope (Leica, WILD macroskop, Heerbrugg, Switzerland) by using fiberoptic illumination. Matrigel implants were then fixed, with skin attached, with 4\% paraformaldehyde:PBS for 2 hours at ambient temperature. Matrigel and adjoining skin was then serially sectioned (2-3 mm thick) with a razor blade and processed for paraffin embedding and histological sectioning. Standard H\&E stain was used to define Matrigel, skin, stromal interface, and neovascular features. Newly formed vessels within the skin/ Matrigel stromal interface were defined as luminal structures containing clearly identifiable blood cells. At least three Matrigel/skin cross-sections, representing approximately a section every 1-2 $\mathrm{mm}$, were manually counted using a $40 \times$ objective, and the number of vessels per field were averaged for at least 5 animals per group. Statistical analysis for significance was performed with the InStat program (GraphPAD Software, San Diego, California) with tests for comparable variance and appropriate parametric or nonparametric $t$ tests applied. Neovascularization was confirmed with immunohistochemical analysis with antimouse collagen type IV (Biodesign International, Kennebunk, Maine) to stain basement membrane or antimouse PECAM-1 (PharMingen, San Diego, California), which stains neovascular and precursor endothelial cells (DeLisser et al, 1997). A chicken anti-hVEGF ${ }_{165}$ polyclonal antibody, described previously (Shih et al, 1999), was used to detect mouse VEGF with immunohistochemistry. In situ hybridization was performed for mouse VEGF and VEGF receptors, flk-1(KDR/VEGF$\mathrm{R} 2$ ), and flt-1(VEGF-R1), as described previously (Claffey et al, 1996).

\section{Antibody Purification, Endotoxin Analysis, and Systemic Treatments}

The chicken anti-VEGF polyclonal antibody was isolated from immunized chicken egg yolk as described (Almeida et al, 1998) and tested for the presence of endotoxin using a Limulus amebocyte QCL-1000 kit (Biowhittaker, Walkersville, Maryland). All anti-VEGF antibody preparations presented less than $1 \mathrm{EU} / \mathrm{mg}$ protein. Control chicken antibody was obtained (Sigma, St. Louis, Missouri) and was found to contain up to $34 \mathrm{EU} / \mathrm{mg}$ protein. The antibody was passed through five successive batch affinity binding steps with an equal volume of polymyxin $B$ agarose beads (Sigma), which reduced the endotoxin concentration to an acceptable level (1.2 EU/mg protein). Antibody treatments of animals with Matrigel/FGF-2 angiogenic implants (10 per group) were injected ip with $150 \mu \mathrm{g}$ of either control chicken or anti-VEGF antibody on Days 1, 3, and 5. Animals were killed on Day 7 and the angiogenic response quantified as described above. Animals in each group were weighed every other day and when killed, and no adverse effects or weight loss were observed. Histologic analysis of spleen, liver, kidney, and axillary lymph nodes revealed no abnormalities, indicating no endotoxin contamination or general infection with the antibody treatment regimens used.

\section{Cell Culture Conditions, Cytokine Treatment, and Transient Transfection Assays}

Balb/c 3T3 embryonic fibroblasts were obtained from American Type Culture Collection and maintained in $10 \%$ calf serum, DMEM, penicillin $(10 \mathrm{U} / \mathrm{ml})$, streptomycin $(10 \mu \mathrm{g} / \mathrm{ml})$, and $2 \mathrm{~mm} \mathrm{~L}-\mathrm{glutamine}$. Cells were grown to $80 \%$ confluence and placed in Opti-MEM (Gibco/BRL, Rockville, Maryland) serum-free media overnight before treatment with either control vehicle (PBS) or FGF-2 (10 ng/ml). Alternatively, cells were exposed to hypoxic conditions $\left(1 \% \mathrm{O}_{2}, 5 \% \mathrm{CO}_{2}, 93 \%\right.$ $\mathrm{N}_{2}$ ) in a humidified triple gas Heraeus model 6060 incubator (Hanau, Germany). Samples of cell culture 
media were collected at various times after treatment, centrifuged at $13,000 \times g$ for 15 minutes at $4^{\circ} \mathrm{C}$, and supernatants frozen at $-80^{\circ} \mathrm{C}$ for analysis in VEGF ELISA assays.

Transient transfection analysis of VEGF-dependent transcription in Balb/c 3T3 cells was performed as described previously (Shih et al, 1999). A construct containing the VEGF promoter containing $1.5 \mathrm{~kb}$ from -1226 to +298 with respect to the transcription start site was followed by a luciferase reporter gene (Shih et al, 1999). The vector was transfected into $80 \%$ confluent Balb/c 3T3 cells using Lipofectamine (Gibco/ $\mathrm{BRL})$ reagent, according to the manufacturer's instructions, for 6 hours followed by 16 hours' recovery in complete media. Cells were then treated with FGF-2 and hypoxia as indicated above, in triplicate. Cell lysates were obtained and protein were determined with the BioRad DC assay (BioRad, Hercules, California) and equal protein used in luciferase assays (Luciferase Assay Kit; Promega, Madison, Wisconsin). Data for triplicate plates was averaged and statistical significance determined by Student's $t$ test.

\section{Cell Adherence Assays}

Cell substratum-dependent adherence assays were performed in triplicate as follows. Cell culture plates were precoated with serum (control plastic), Matrigel at $50 \mu \mathrm{g} / \mathrm{ml}(\mathrm{ECM})$, or fibronectin at $50 \mu \mathrm{g} / \mathrm{ml}$ (Fn) under sterile conditions. Cells were then trypsinized and plated in Opti-MEM serum-free media with or without FGF-2 at $10 \mathrm{ng} / \mathrm{ml}$ for 8 hours. Cells were photographed using an inverted Zeiss axiophot before RNA isolation and analysis as described below.

\section{RNA Isolation and Northern Blot Analysis}

RNA isolation and Northern blot analyses were performed as described previously (Shih et al, 1999). Probes used were the mouse VEGF cDNA (Claffey et al, 1992) and the ribosome associated protein, 36B4, as control (Masiakowski et al, 1982). Radioactive DNA probes were synthesized from isolated cDNA fragments using the MultiPrime Kit (Amersham, Arlington Heights, Illinois). Blots were stringently washed at $0.5 \times$ SSC, $1 \%$ SDS at $65^{\circ} \mathrm{C}$ and exposed to either X-ray film (Kodak X-Omat MR; Eastman Kodak, Rochester, New York) or phosphorimage cassettes (Molecular Dynamics, Sunnyvale, California) for quantitative analysis. VEGF signals were normalized to 36B4 control, averaged, and compared for statistical significance by Student's $t$ test.

\section{VEGF ELISA Assays}

Analysis of cell supernatants from triplicate plates for VEGF protein was performed as previously described (Shih et al, 1999). The capture antibody used was the chicken anti-VEGF polyclonal antibody coated at 5 $\mu \mathrm{g} / \mathrm{ml}$ and the goat antimouse VEGF polyclonal antibody ( $R$ and D Systems, Minneapolis, Minnesota) used as detection antibody at $5 \mu \mathrm{g} / \mathrm{ml}$, followed by horseradish peroxidase conjugated antigoat IgG at $0.5 \mu \mathrm{g} / \mathrm{ml}$ (Sigma). The horseradish peroxidase substrate used was the
TMB substrate (Kirkegaard and Perry Laboratories, Gaithersburg, Maryland). Color development was recorded on a 96-well plate reader (Thermodynamics, Molecular Devices Corporation, Sunnyvale, California). Quantitation of samples was determined from the least squares regression analysis of a linear range standard curve obtained with recombinant mouse VEGF as control (R and D Systems).

\section{Acknowledgements}

We wish to thank Kathy Tognozzi for technical assistance and Donald Senger for critical reagents and helpful discussions.

\section{References}

Abdulrauf SI, Edvardsen K, Ho KL, Yang XY, Rock JP, and Rosenblum ML (1998). Vascular endothelial growth factor expression and vascular density as prognostic markers of survival in patients with low-grade astrocytoma. J Neurosurg 88:513-520.

Almeida CM, Kanashiro MM, Rangel Filho FB, Mata MF, Kipnis TL, and da Silva WD (1998). Development of snake antivenom antibodies in chickens and their purification from yolk. Vet Rec 143:579-584.

Andrade SP, Machado RD, Teixeira AS, Belo AV, Tarso AM, and Beraldo WT (1997). Sponge-induced angiogenesis in mice and the pharmacological reactivity of the neovasculature quantitated by a fluorimetric method. Microvasc Res 54:253-261.

Asahara T, Bauters C, Zheng LP, Takeshita S, Bunting S, Ferrara N, Symes JF, and Isner JM (1995). Synergistic effect of vascular endothelial growth factor and basic fibroblast growth factor on angiogenesis in vivo. Circulation 92:||365-I|371.

Asano M, Yukita A, Matsumoto T, Kondo S, and Suzuki H (1995). Inhibition of tumor growth and metastasis by an immunoneutralizing monoclonal antibody to human vascular endothelial growth factor/vascular permeability factor 121 . Cancer Res 55:5296-5301.

Axelsson K, Ljung BM, Moore DH 2nd, Thor AD, Chew KL, Edgerton SM, Smith HS, and Mayall BH (1995). Tumor angiogenesis as a prognostic assay for invasive ductal breast carcinoma [see comments]. J Natl Cancer Inst 87:997-1008.

Banai S, Shweiki D, Pinson A, Chandra M, Lazarovici G, and Keshet E (1994). Upregulation of vascular endothelial growth factor expression induced by myocardial ischaemia: Implications for coronary angiogenesis. Cardiovasc Res 28:11761179.

BenEzra D, Griffin BW, Maftzir G, and Aharonov O (1993). Thrombospondin and in vivo angiogenesis induced by basic fibroblast growth factor or lipopolysaccharide. Invest Ophthalmol Vis Sci 34:3601-3608.

Berger DP, Herbstritt L, Dengler WA, Marme D, Mertelsmann $\mathrm{R}$, and Fiebig HH (1995). Vascular endothelial growth factor (VEGF) mRNA expression in human tumor models of different histologies. Ann Oncol 6:817-825.

Berger W, Setinek U, Mohr T, Kindas-Mugge I, Vetterlein M, Dekan G, Eckersberger F, Caldas C, and Micksche M (1999). Evidence for a role of FGF-2 and FGF receptors in the proliferation of non-small cell lung cancer cells. Int $\mathrm{J}$ Cancer 83:415-423. 
Brown L, Berse B, Jackman R, Tognazzi K, Guidi A, Dvorak H, Senger D, Connolly J, and Schnitt S (1995). Expression of vascular permeability factor (vascular endothelial growth factor) and its receptors in breast cancer. Hum Pathol 26:86-91.

Brown LF, Berse B, Jackman RW, Tognazzi K, Manseau EJ, Senger DR, and Dvorak HF (1993). Expression of vascular permeability factor (vascular endothelial growth factor) and its receptors in adenocarcinomas of the gastrointestinal tract. Cancer Res 53:4727-4735.

Brown LF, Guidi AJ, Schnitt SJ, Van De Water L, Iruela-Arispe ML, Yeo TK, Tognazzi K, and Dvorak HF (1999). Vascular stroma formation in carcinoma in situ, invasive carcinoma, and metastatic carcinoma of the breast. Clin Cancer Res 5:1041-1056.

Carmeliet P, Dor Y, Herbert JM, Fukumura D, Brusselmans K, Dewerchin M, Neeman M, Bono F, Abramovitch R, Maxwell P, Koch CJ, Ratcliffe P, Moons L, Jain RK, Collen D, Keshert E, and Keshet E (1998). Role of HIF-1alpha in hypoxiamediated apoptosis, cell proliferation and tumour angiogenesis [published erratum appears in Nature 395:525]. Nature 394:485-490.

Charvat S, Duchesne M, Parvaz P, Chignol MC, Schmitt D, and Serres M (1999). The up-regulation of vascular endothelial growth factor in mutated Ha-ras $\mathrm{HaCaT}$ cell lines is reduced by a farnesyl transferase inhibitor. Anticancer Res 19:557-561.

Claffey KP, Brown LF, del Aguila LF, Tognazzi K, Yeo KT, Manseau EJ, and Dvorak HF (1996). Expression of vascular permeability factor/vascular endothelial growth factor by melanoma cells increases tumor growth, angiogenesis, and experimental metastasis. Cancer Res 56:172-181.

Claffey KP and Robinson GS (1996). Regulation of VEGF/NPF expression in tumor cells: Consequences for tumor growth and metastasis. Cancer Metastasis Rev 15:165-176.

Claffey KP, Wilkison WO, and Spiegelman BM (1992). Vascular endothelial growth factor. Regulation by cell differentiation and activated second messenger pathways. J Biol Chem 267:16317-16322.

Couffinhal T, Silver M, Zheng LP, Kearney M, Witzenbichler $\mathrm{B}$, and Isner JM (1998). Mouse model of angiogenesis. Am J Pathol 152:1667-1679.

Damert A, Machein M, Breier G, Fujita M, Hanahan D, Risau W, and Plate K (1997). Up-regulation of vascular endothelial growth factor expression in a rat glioma is conferred by two distinct hypoxia-driven mechanisms. Cancer Res 57:38603864.

Davol PA and Frackelton AR Jr (1999). Targeting human prostatic carcinoma through basic fibroblast growth factor receptors in an animal model: Characterizing and circumventing mechanisms of tumor resistance. Prostate 40:178191.

DeLisser HM, Christofidou-Solomidou M, Strieter RM, Burdick MD, Robinson CS, Wexler RS, Kerr JS, Garlanda C, Merwin JR, Madri JA, and Albelda SM (1997). Involvement of endothelial PECAM-1/CD31 in angiogenesis. Am J Pathol 151:671-677.

Dellian M, Witwer BP, Salehi HA, Yuan F, and Jain RK (1996). Quantitation and physiological characterization of angiogenic vessels in mice: Effect of basic fibroblast growth factor, vascular endothelial growth factor/vascular permeability factor, and host microenvironment [see comments]. Am J Pathol 149:59-71.
Dosquet C, Coudert MC, Lepage E, Cabane J, and Richard F (1997). Are angiogenic factors, cytokines, and soluble adhesion molecules prognostic factors in patients with renal cell carcinoma? [in process citation] Clin Cancer Res 3:24512458.

Dvorak HF (1988). Tumor stroma. In: Colvin RB, Bahn AK, and McCluskey RT, editors. Diagnostic immunopathology. New York: Raven Press, 401-420.

Dvorak HF, Nagy JA, Berse B, Brown LF, Yeo K-T, Yeo T-K, Dvorak AM, Van De Water L, Sioussat TM, and Senger DR (1992). Vascular permeability factor, fibrin, and the pathogenesis of tumor stroma formation. Ann N Y Acad Sci 667:101111.

Flamme I, Krieg M, and Plate KH (1998). Up-regulation of vascular endothelial growth factor in stromal cells of hemangioblastomas is correlated with up-regulation of the transcription factor HRF/HIF-2alpha. Am J Pathol 153:25-29.

Fleming RY, Ellis LM, Parikh NU, Liu W, Staley CA, and Gallick GE (1997). Regulation of vascular endothelial growth factor expression in human colon carcinoma cells by activity of src kinase. Surgery 122:501-507.

Florkiewicz RZ, Anchin J, and Baird A (1998). The inhibition of fibroblast growth factor-2 export by cardenolides implies a novel function for the catalytic subunit of $\mathrm{Na}+, \mathrm{K}+$-ATPase. J Biol Chem 273:544-551.

Florkiewicz RZ, Majack RA, Buechler RD, and Florkiewicz E (1995). Quantitative export of FGF-2 occurs through an alternative, energy-dependent, non-ER/Golgi pathway. J Cell Physiol 162:388-399.

Folkman J (1992). The role of angiogenesis in tumor growth. Semin Cancer Biol 3:65-71.

Folkman J and Hanahan D (1991). Switch to the angiogenic phenotype during tumorigenesis. Princess Takamatsu Symp 22:339-347.

Forsythe JA, Jiang BH, lyer NV, Agani F, Leung SW, Koos $\mathrm{RD}$, and Semenza GL (1996). Activation of vascular endothelial growth factor gene transcription by hypoxia-inducible factor 1. Mol Cell Biol 16:4604-4613.

Fukumura D, Xavier R, Sugiura T, Chen Y, Park EC, Lu N, Selig M, Nielsen G, Taksir T, Jain RK, and Seed B (1998). Tumor induction of VEGF promoter activity in stromal cells. Cell 94:715-725.

Gasparini G and Harris AL (1995). Clinical importance of the determination of tumor angiogenesis in breast carcinoma: Much more than a new prognostic tool. J Clin Oncol 13:765782.

Goto F, Goto K, Weindel K, and Folkman J (1993). Synergistic effects of vascular endothelial growth factor and basic fibroblast growth factor on the proliferation and cord formation of bovine capillary endothelial cells within collagen gels [see comments]. Lab Invest 69:508-517.

Grugel S, Finkenzeller G, Weindel K, Barleon B, and Marme D (1995). Both v-Ha-Ras and v-Raf stimulate expression of the vascular endothelial growth factor in NIH 3T3 cells. J Biol Chem 270:25915-25919.

Guidi AJ, Abu-Jawdeh G, Berse B, Jackman RW, Tognazzi K, Dvorak HF, and Brown LF (1995). Vascular permeability factor (vascular endothelial growth factor) expression and angiogenesis in cervical neoplasia. J Natl Cancer Inst 87: $1237-1245$. 
Hata Y, Rook SL, and Aiello LP (1999). Basic fibroblast growth factor induces expression of VEGF receptor KDR through a protein kinase $C$ and p44/p42 mitogen-activated protein kinase-dependent pathway. Diabetes 48:1145-1155.

Hippenstiel S, Krull M, Ikemann A, Risau W, Clauss M, and Suttorp N (1998). VEGF induces hyperpermeability by a direct action on endothelial cells. Am J Physiol 274:L678L684.

Hu DE and Fan TP (1995a). Protein kinase C inhibitor calphostin $\mathrm{C}$ prevents cytokine-induced angiogenesis in the rat. Inflammation 19:39-54.

Hu DE and Fan TP (1995b). Suppression of VEGF-induced angiogenesis by the protein tyrosine kinase inhibitor, lavendustin $\mathrm{A}$. Br J Pharmacol 114:262-268.

Huang JC, Liu DY, and Dawood MY (1998). The expression of vascular endothelial growth factor isoforms in cultured human endometrial stromal cells and its regulation by 17 beta-oestradiol. Mol Hum Reprod 4:603-607.

Ittman M and Mansukhani A (1997). Expression of fibroblast growth factors (FGFs) and FGF receptors in human prostate. J Urol 157:351-356.

Jaeger TM, Weidner N, Chew K, Moore DH, Kerschmann RL, Waldman FM, and Carroll PR (1995). Tumor angiogenesis correlates with lymph node metastases in invasive bladder cancer. J Urol 154:69-71.

Kenyon BM, Voest EE, Chen CC, Flynn E, Folkman J, and D'Amato RJ (1996). A model of angiogenesis in the mouse cornea. Invest Ophthalmol Vis Sci 37:1625-1632.

Kiefer P, Peters G, and Dickson C (1993). Retention of fibroblast growth factor 3 in the Golgi complex may regulate its export from cells. Mol Cell Biol 13:5781-5793.

Kondo S, Asano M, and Suzuki H (1993). Significance of vascular endothelial growth factor/vascular permeability factor for solid tumor growth, and its inhibition by the antibody. Biochem Biophys Res Commun 194:1234-1241.

Kumar R, Kuniyasu H, Bucana CD, Wilson MR, and Fidler IJ (1998). Spatial and temporal expression of angiogenic molecules during tumor growth and progression. Oncol Res 10:301-311.

Levine AC, Liu XH, Greenberg PD, Eliashvili M, Schiff JD, Aaronson SA, Holland JF, and Kirschenbaum A (1998). Androgens induce the expression of vascular endothelial growth factor in human fetal prostatic fibroblasts. Endocrinology 139:4672-4678.

Mandriota SJ and Pepper MS (1997). Vascular endothelial growth factor-induced in vitro angiogenesis and plasminogen activator expression are dependent on endogenous basic fibroblast growth factor. J Cell Sci 110:2293-2302.

Masiakowski P, Breathnach R, Bloch J, Gannon F, Krust A, and Chambon $P$ (1982). Cloning of a ribosome-associated protein cDNA, 36B4. Nucleic Acids Res 10:7895-7903.

Mattern J, Koomagi R, and Volm M (1997). Coexpression of VEGF and bFGF in human epidermoid lung carcinoma is associated with increased vessel density. Anticancer Res 17:2249-2252.

Maxwell PH, Dachs GU, Gleadle JM, Nicholls LG, Harris AL, Stratford IJ, Hankinson O, Pugh CW, and Ratcliffe PJ (1997). Hypoxia-inducible factor-1 modulates gene expression in solid tumors and influences both angiogenesis and tumor growth. Proc Natl Acad Sci USA 94:8104-8109.
Mise M, Arii S, Higashituji H, Furutani M, Niwano M, Harada T, Ishigami S, Toda Y, Nakayama H, Fukumoto M, Fujita J, and Imamura M (1996). Clinical significance of vascular endothelial growth factor and basic fibroblast growth factor gene expression in liver tumor. Hepatology 23:455-464.

Okada F, Rak JW, Croix BS, Lieubeau B, Kaya M, Roncari L, Shirasawa S, Sasazuki T, and Kerbel RS (1998). Impact of oncogenes in tumor angiogenesis: Mutant K-ras upregulation of vascular endothelial growth factor/vascular permeability factor is necessary, but not sufficient for tumorigenicity of human colorectal carcinoma cells. Proc Natl Acad Sci USA 95:3609-3614.

Okita S, Kondoh S, Shiraishi K, Kaino S, Hatano S, and Okita K (1998). Expression of vascular endothelial growth factor correlates with tumor progression in gallbladder cancer. Int $\mathrm{J}$ Oncol 12:1013-1018.

Passaniti A, Taylor RM, Pili R, Guo Y, Long PV, Haney JA, Pauly RR, Grant DS, and Martin GR (1992). A simple, quantitative method for assessing angiogenesis and antiangiogenic agents using reconstituted basement membrane, heparin, and fibroblast growth factor. Lab Invest 67:519-528.

Pepper MS, Ferrara N, Orci L, and Montesano R (1991). Vascular endothelial growth factor (VEGF) induces plasminogen activators and plasminogen activator inhibitor-1 in microvascular endothelial cells. Biochem Biophys Res Commun 181:902-906.

Pepper MS, Ferrara N, Orci L, and Montesano R (1992). Potent synergism between vascular endothelial growth factor and basic fibroblast growth factor in the induction of angiogenesis in vitro. Biochem Biophys Res Commun 189:824831.

Pepper MS, Mandriota SJ, Jeltsch M, Kumar V, and Alitalo K (1998). Vascular endothelial growth factor (VEGF)-C synergizes with basic fibroblast growth factor and VEGF in the induction of angiogenesis in vitro and alters endothelial cell extracellular proteolytic activity. J Cell Physiol 177:439-452.

Plate KH, Breier G, Millauer B, Ullrich A, and Risau W (1993). Up-regulation of vascular endothelial growth factor and its cognate receptors in a rat glioma model of tumor angiogenesis. Cancer Res 53:5822-5827.

Plate KH, Breier G, Weich HA, Mennel HD, and Risau W (1994). Vascular endothelial growth factor and glioma angiogenesis: Coordinate induction of VEGF receptors, distribution of VEGF protein and possible in vivo regulatory mechanisms. Int J Cancer 59:520-529.

Potgens AJ, Westphal HR, de Waal RM, and Ruiter DJ (1995). The role of vascular permeability factor and basic fibroblast growth factor in tumor angiogenesis. Biol Chem Hoppe Seyler 376:57-70.

Rak J, Mitsuhashi Y, Bayko L, Filmus J, Sasazuki T, and Kerbel R (1995a). Mutant ras oncogenes upregulate VEGF expression: Implications for induction and inhibition of tumor angiogenesis. Cancer Res 55:4575-4580.

Rak J, Mitsuhashi Y, Bayko L, Filmus J, Shirasawa S, Sasazuki T, and Kerbel RS (1995b). Mutant ras oncogenes upregulate VEGF/VPF expression: Implications for induction and inhibition of tumor angiogenesis. Cancer Res 55:4575-4580.

Ribatti D, Gualandris A, Bastaki M, Vacca A, lurlaro M, Roncali L, and Presta M (1997). New model for the study of angiogenesis and antiangiogenesis in the chick embryo chorioallantoic membrane: The gelatin sponge/chorioallantoic membrane assay. J Vasc Res 34:455-463. 
Schmidt NO, Westphal M, Hagel C, Ergun S, Stavrou D, Rosen EM, and Lamszus K (1999). Levels of vascular endothelial growth factor, hepatocyte growth factor/scatter factor and basic fibroblast growth factor in human gliomas and their relation to angiogenesis. Int $\mathrm{J}$ Cancer 84:10-18.

Seghezzi G, Patel S, Ren CJ, Gualandris A, Pintucci G, Robbins ES, Shapiro RL, Galloway AC, Rifkin DB, and Mignatti P (1998). Fibroblast growth factor-2 (FGF-2) induces vascular endothelial growth factor (VEGF) expression in the endothelial cells of forming capillaries: An autocrine mechanism contributing to angiogenesis. J Cell Biol 141:1659-1673.

Senger DR, Brown LF, Claffey KP, and Dvorak HF (1994). Vascular permeability factor, tumor angiogenesis and stroma generation. Invasion Metastasis 14:385-394.

Senger DR, Connolly D, Perruzzi CA, Alsup D, Nelson R, Leimgruber R, Feder J, and Dvorak HF (1987). Purification of a vascular permeability factor (VPF) from tumor cell conditioned medium. In: Federation proceedings, vol 46. Bethesda: Federation of American Societies for Experimental Biology, 2102.

Senger DR, Connolly DT, Van De Water L, Feder J, and Dvorak HF (1990). Purification and $\mathrm{NH}_{2}$-terminal amino acid sequence of guinea pig tumor-secreted vascular permeability factor. Cancer Res 50:1774-1778.

Senger DR, Ledbetter SR, Claffey KP, PapadopoulosSergiou A, Peruzzi CA, and Detmar M (1996). Stimulation of endothelial cell migration by vascular permeability factor/ vascular endothelial growth factor through cooperative mechanisms involving the alphavbeta3 integrin, osteopontin, and thrombin. Am J Pathol 149:293-305.

Shi YP and Ferrara N (1999). Oncogenic ras fails to restore an in vivo tumorigenic phenotype in embryonic stem cells lacking vascular endothelial growth factor (VEGF). Biochem Biophys Res Commun 254:480-483.

Shih S-C, Mullen A, Abrams K, Mukhopadhyay D, and Claffey K (1999). Role of protein kinase $C$ isoforms in phorbol ester-induced vascular endothelial growth factor expression in human glioblastoma cells. J Biol Chem 274:15407-15414.

Shweiki D, Neeman M. Itin A, and Keshet E (1995). Induction of vascular endothelial growth factor expression by hypoxia and by glucose deficiency in multicell spheroids: Implications for tumor angiogenesis. Proc Natl Acad Sci USA 92:768-772.

Stein I, Neeman M, Shweiki D, Itin A, and Keshet E (1995). Stabilization of vascular endothelial growth factor mRNA by hypoxia and hypoglycemia and coregulation with other ischemia-induced genes. Mol Cell Biol 15:5363-5368.

Stone J, Itin A, Alon T, Pe'er J, Gnessin H, Chan-Ling T, and Keshet $E$ (1995). Development of retinal vasculature is mediated by hypoxia-induced vascular endothelial growth factor (VEGF) expression by neuroglia. J Neurosci 15:4738-4747.

Sumitomo S, Okamoto Y, Mizutani G, Kudeken W, Mori M, and Takai $Y$ (1999). Immunohistochemical study of fibroblast growth factor-2 (FGF-2) and fibroblast growth factor receptor (FGF-R) in experimental squamous cell carcinoma of rat submandibular gland. Oral Oncol 35:98-104.
Tamiya S, Ueki T, and Tsuneyoshi M (1998). Expressions of basic fibroblast growth factor and fibroblast growth factor receptor mRNA in soft tissue tumors by in situ hybridization. Mod Pathol 11:533-536.

Toi M, Inada K, Suzuki H, and Tominaga T (1995). Tumor angiogenesis in breast cancer: Its importance as a prognostic indicator and the association with vascular endothelial growth factor expression. Breast Cancer Res Treat 36:193204.

Ueki T, Koji T, Tamiya S, Nakane PK, and Tsuneyoshi M (1995). Expression of basic fibroblast growth factor and fibroblast growth factor receptor in advanced gastric carcinoma. J Pathol 177:353-361.

Volm M, Koomagi R, and Mattern J (1999). PD-ECGF, bFGF, and VEGF expression in non-small cell lung carcinomas and their association with lymph node metastasis. Anticancer Res 19:651-655.

Weidner N, Folkman J, Pozza F, Bevilacqua P, Allred EN, Moore DH, Meli S, and Gasparini G (1992). Tumor angiogenesis: A new significant and independent prognostic indicator in early-stage breast carcinoma [see comments]. J Natl Cancer Inst 84:1875-1887.

Weidner N, Semple JP, Welch WR, and Folkman J (1991). Tumor angiogenesis and metastasis: Correlation in invasive breast carcinoma. N Engl J Med 324:1-8.

Wilting J, Christ B, and Bokeloh M (1991). A modified chorioallantoic membrane (CAM) assay for qualitative and quantitative study of growth factors. Studies on the effects of carriers, PBS, angiogenin, and bFGF. Anat Embryol (Berl) 183:259-271.

Wilting J, Christ B, Bokeloh M, and Weich HA (1993). In vivo effects of vascular endothelial growth factor on the chicken chorioallantoic membrane. Cell Tissue Res 274:163-172.

Wu J (1996). Apoptosis and angiogenesis: Two promising tumor markers in breast cancer (review). Anticancer Res 16:2233-2239.

Xerri L, Battyani Z, Grob JJ, Parc P, Hassoun J, Bonerandi JJ, and Birnbaum D (1996). Expression of FGF1 and FGFR1 in human melanoma tissues. Melanoma Res 6:223-230.

Yoshimura N, Sano H, Hashiramoto A, Yamada R, Nakajima $\mathrm{H}$, Kondo M, and Oka T (1998). The expression and localization of fibroblast growth factor-1 (FGF-1) and FGF receptor-1 (FGFR-1) in human breast cancer. Clin Immunol Immunopathol 89:28-34.

Ziche M, Morbidelli L, Choudhuri R, Zhang HT, Donnini S, Granger HJ, and Bicknell R (1997). Nitric oxide synthase lies downstream from vascular endothelial growth factor-induced but not basic fibroblast growth factor-induced angiogenesis. J Clin Invest 99:2625-2634. 